\title{
Contexts of Twinship: Discourses and Generation
}

Kate Bacon

\section{Notes on Contributor}

Kate Bacon is Senior Lecturer in Sociology at the University of Central Lancashire, Preston, UK. Her research and teaching explore themes from within Childhood Studies including the social construction of childhood, structure and agency, childhood identities (especially twinship and sibship) and children and citizenship.

\section{Abstract}

Much of the research relating to twins is concentrated in biology and psychology where twins have been used as methodological tools for testing for the relative influences of nature and nurture. This chapter demonstrates a sociological approach to the study of twinship by situating twinship within a social and cultural context. It examines how discourses of twinship, childhood and 'growing up' bring meaning to and frame our understanding of twinship. It also draws attention to the significance of family life, especially family relationships and generation in contextualising twins' experiences and variously facilitating and inhibiting their agency. 


\section{Introduction: Research on twins}

There are around 10,000 multiple births each year in England and Wales - around 1 in every 65 births. Due to the increase in technologies to assist conception (such as IVF) and the fact that women are having children later in life, the number of multiple births has been on the increase from the 1970s (McKay 2010).

Most research on twins has been concerned to investigate the influence of heredity and environment. Traditionally, this utilises the 'twin method' whereby researchers compare identical and non-identical twins in order to see how much the environment shapes the phenomenon under study (Mittler 1971). Although criticised for assuming that the influence of the environment is the same in the two types of twins (for instance see Ainslie, Olmstead \& O'Loughlin 1987; Zazzo, 1987), the classic 'twin method' has been used by medical geneticists and researchers to test how far diseases are genetically determined. Psychological studies have examined the role of genetics and environment in determining temperament, personality and cognition (see Kozlak 1978; Newman 1942). Whilst some of the psychological/psychoanalytical studies (Burlingham 1952; Koch 1966) reveal glimpses of how parents and the general public think about twins, their main focus remains on charting the development of twins and (often problems with) their identity formation.

Anthropology has examined the cultural beliefs and customs relating to twins (mainly in nonWestern societies) and demonstrated how ideas about twins are culturally variable. Amongst other things, twins have been variously associated with adultery, animalistic reproduction, mystical powers and god-given faculties. In some cultures, they confer special honour in other cultures they invite fear (see Corney 1977 for an overview).

In contrast to anthropology, sociology has paid little attention to twins. Indeed, although the sociological study of sibship is a growing area of contemporary sociology, there are still relatively few empirical sociological studies of twinship. Taking a sociological perspective to twinship means examining twinship as a social and (from my perspective, taking account of the influence of anthropology too) also a cultural phenomenon. This involves examining how cultural ideas and social attitudes shape twinship, how twinship as a social identity is built up 
and established as meanings are played out and negotiated in everyday life. It involves examining how broader social processes and changes as well as micro-level interactions shape twins' experiences of being twins. In her book Exploring Twins, Stewart argues that twinship is 'an irreducibly social phenomenon' (2003, p. 150). She considers the social consequences of twinship for families and twins and includes one chapter reviewing findings from her UKbased empirical studies of parents' and the general public's attitudes towards twins. My book Twins in Society (2010), relays findings from another UK empirical study conducted with 15 parents of twins, 12 child twins, 9 adult twins and 5 siblings of twins. The project examined how twins negotiate their identities as they move through the life course and also paid specific attention to representations of twinship in popular culture and parenting guides (for parents of twins).

This chapter utilises aspects of this research to demonstrate how taking a sociological perspective can reveal how twinship is shaped for twins and by twins. To set the scene for this discussion, the Chapter begins by introducing two parents that I researched: Clare and Anthony. The Chapter then returns to discuss the key themes highlighted by this case study.

\section{Clare \& Anthony}

Anthony and Clare were parents to non-identical 8-year-old twins, Ash and Harry. They all lived in a 3-bedroomed house on a housing estate on the edge of a town in the North of England. Anthony and Clare were both working in manual jobs, doing shift work. In many respects their views on parenting and ideal family life might be described as 'traditional'. For Clare, an ideal family was parents with two children: one boy and one girl. For Anthony, gender was important here - 'obviously men want boys'. Anthony and Clare wanted their children to be kept 'as young and innocent' (Clare) for as long as possible 'in like a little cocoon' (Clare) (Bacon, 2010: 57). They didn't really like them playing outside on the street in case hanging around with the other children that came to 'congregate' (Clare) there meant they ended up taking the blame for something and getting into trouble. However, they did not want them to be so cocooned that this innocence prevented them from becoming independent individuals. They worried they were being too overprotective. Whilst they valued their twins' closeness - recounting examples of how Ash and Harry liked to be 
together, chose to share a bedroom, sometimes still wanted to sleep together, and missed each other when they were apart - they also sensed that too much dependence could be problematic.

Although they were glad they weren't identical, Clare decided to dress her twins 'the same' in identical outfits. 'I always dress them alike'. Whilst, both Clare and Anthony worried that they were not treating them like 'individuals' Clare told me 'I just like to see 'em in [the] same clothes' (Bacon, 2010: 72).

Growing up was envisaged as a process that would modify these expressions of togetherness and sameness. Clare supposed that as her twins 'get older they will change'. One aspect of this change would be when her children objected to wearing the same clothes: 'until they say "oh I'm not wearing what he's wearing" I'll continue to do it' (Bacon, 2010: 72).Another aspect would be spending less time together as they move into different classes at comprehensive school and get their own friends and eventually move out of home.

For these parents, growing up also meant getting older, more capable and more knowing but Clare and Anthony saw themselves as taking a leading role in deciding exactly what was appropriate for their children to see and know. For instance, they prevented their children from watching a film rated 12 year olds because it was deemed 'not suitable'. Their decision was final - as Clare put it, that was the 'top and bottom of it'. Anthony felt comfortable with Ash and Harry playing on the play station or watching TV programmes that contained some violence 'as long as they can distinguish which is fact and fiction'. At the same time he said that 'where sex and swearing come in, you know, they're not an age group where they can take that on board.' 'When they need to know about things like that we'll tell 'em, it's as simple as that' (Bacon, 2010: 57).

\section{EXPLORING DIMENSIONS OF CONTEXT}

As Frankel (2017) notes, in order to fully understand children's everyday lives it is important to examine the way in which the wider context of society, including the socially constructed nature of childhood, shapes interactional settings and the practices that take shape there. 
This case study illustrates how twinship is contexualised by a range of social structures and processes. First, it shows how parents work with and utilise various discourses of childhood and twinship to inform their views on how they should raise their children and be 'good parents'. Central to these parents are discourses about childhood innocence, development and becoming. Second, it provides insight into how inter-generational relationships between parents and children contextualise children's agency - the extent to which children can shape their own lives and the lives of other people. Thirdly, we catch glimpses of how the experience of twinship is also shaped by a range of material conditions (including the economic capital of parents and the organisation and use of physical space within the home) and broader social changes such as the growing child-centeredness of family life. The next sections explore these in more detail.

\section{(i) Discourses}

Discourses are collections of ideas that help to bring meaning to the social world and shape the knowledge we have about it. This includes knowledge about childhood and twinship. As Foucault (1980) notes, there is a close relationship between knowledge and power. Discourses can be used to control behaviour, they shape how we think, feel and act. Some discourses may also be deemed more 'legitimate' than others and through their domination, take the status of 'common sense'. Discourses of childhood and twinship are products of culture and history and as such can vary over time and space.

\section{Discourses of childhood and growing up}

Research within Childhood Studies (see James, Jenks \& Prout 1998; Hendrick 2015) has highlighted a number of dominant (Western) discourses of childhood including children as evil, innocent and naturally developing. The evil child is innately wilful and requires adult regulation and control to keep them on the 'right' path. These children should avoid 'bad' places in case they fall into bad company (James et al. 1998). From its mythological foundation in the Christian doctrine of Original Sin, this discourse has persisted over time - through the religious Puritanism of the $16^{\text {th }}$ and $17^{\text {th }}$ Centuries, the Poor Laws and Dickensian novels of the $19^{\text {th }}$ Century. It is also very much a feature of our contemporary belief system too - 
evident in the 1998 Crime and Disorder Act's removal of the presumption of doli incapax and contemporary public concerns about the dangers that children (as well as adults) present in public space. We can also see glimpses of this in Clare's worries about the other kids off the street that 'come and congregate'.

Created and sustained by educational, legal and health policies, the discourse of the innocent child arguably remains one of the most dominant images of childhood, at least in public (Jenks 1996; McNamee 2016). It is at the forefront of Clare and Anthony's 'public' account too. Historically associated with Rousseau and the Romantic poets (although, it extends beyond this) this discourse pictures children as having a natural goodness that places them closer to nature. Adults should learn from this and cherish it in their children. 'Devoid of all morality in his actions, [the child] can do nothing which is morally bad and which merits either punishment or reprimand' (Rousseau 1979 [1762], p. 92). In contrast, adult society can corrupt children. Children, Rousseau argued, should be left to mature in a natural and orderly way moving from relying on sensual experience to intellectual and analytical thinking and later, moral reasoning. Adults are tasked with regulating the environment that children grow up in, in order to ensure that they do not encounter things beyond their comprehension. Rousseau warns the adult that 'You will not be the child's master if you are not the master of all that surrounds him' (1979 [1762], p. 95). This image of childhood therefore positions the child as being different to adults, requiring special treatment and care (Jenks 1996).

Central to this image of the innocent child are notions of dependency and development. Dependency defines the child as different, Other and 'in need' (Hockey and James 1993). Yet 'Childish dependency on parental care is expected to give way at a certain age to independent adulthood' (Hockey and James 2003, p. 167). In Western societies, Individualistic, knowledgeable independence is the marker of adult status and the achievement of full personhood. Children achieve this, so the story goes, by progressing through a series of stages at particular ages.

During the nineteenth and especially twentieth centuries children became the focus of scientific attention. Their bodies were weighed, measured and observed. Piaget, who was very much influenced by Rousseau's ideas, was an influential twentieth century 
developmental theorist. He carried out a series of experiments on children in order to construct a theory of how children's thinking skills develop through four distinct stages - from thought driven by sensory perception to rational, abstract and hypothetical thinking (Woodhead, 2013). He also suggested that children confused fantasy and reality (Piaget 1929, 1930).

Even though development 'is neither a precise concept, nor a neutral one' (Woodhead 2013, p. 109), notions of 'age and stage', 'normal' and 'abnormal' development (including children's inability to distinguish fact from fiction) have filtered down to the level of common-sense (Sharon and Wooley 2004). It is evident that these discourses feed into and shape how Anthony and Clare parent their children. The significance that they attribute to age for assessing their children's levels of competence and skill, as well as what is appropriate and inappropriate parenting practice are evident. Their /concerns to cherish and protect their innocent children reflect Western cultural obsessions with constructing the child as a symbol of dependency and the shift from children being economically valuable to being symbolically and emotionally priceless (Zelizer 1985). Adults invest huge amounts of time and emotion in their children's childhoods and they construct idealised notions of childhood that help them to sustain some belief in stability amidst the change and uncertainty that characterises many other aspects of social life and social relationships (Gillis 2003; Giddens 1991). Children are now seen as 'unequivocal sources of love, but also as partners in the most fundamental, unchosen, unnegotiated form of relationship' (Jenks 1996, p. 107). Thus, whilst Anthony and Clare's account may be 'personal' to them, they also reflect much broader public issues and social patterns.

\section{Discourses of twinship and growing up}

These related ideas of innocence and dependence parallel discourses of twinship. Twins are commonly imagined as being the same, close and together (Bacon 2010). In her two-stage study, Stewart (2003) collected the views of 100 parents of twins and then the views of 302 members of the general public. Her findings revealed how we tend to associate twins with identicalness - not only do parents commonly get asked if their twins are identical, but as a general population we also tend to associate the word twins with the word 'identical'. 
Reflecting this, Clare told me 'people obviously do think that they should be [the same], they do everything the same way and they react the same way which they are surprised when they don't... people do think that they should be exactly the same...'. In everyday social life, twins are often talked about as 'two-peas in a pod', 'joined at the hip' or 'soul mates'. They are also depicted by the media and advertising as the same - for instance to show the benefits of using one product brand over another or to promote the value of two-for-one deals (see Bacon, 2010). Describing the stereotype of twinship, Leonard (1961, p. 301) writes, '[t] wins look alike, think alike. They never fight. They have a closer relationship than any other known to mankind'.

When these discourses are positioned alongside discourses of childhood it becomes apparent that twinship (with identical twinship representing the very epitome of twinship) is an intensification of the symbol of the child. Whilst children are thought to have the seeds of individuality and are also deemed to be dependent on their parents, twins are commonly thought to lack individuality by virtue of being 'twins' and are assumed to be dependent on each other as well as their parents. Being a twin then, is constructed as another way of being a child; but a more 'childish' child (Bacon 2010). This, explains why $17 \%$ of the 302 respondents in Stewarts' (2003) study also associated the word twins with 'babies and children'. It may also explain why so many twins feature in children's literature.

On the one hand, social expectations about how twins should grow up are not completely different to other children. They still hinge around children growing up to become independent individuals. On the other hand, there are also some important differences. First, theories about how twins grow up relate not just to children's relationship with their parents but also their relationship with each other too. Ideas about how twins grow up therefore also incorporate how sameness, togetherness and closeness are to be managed across the life course. Although many of the parents I spoke with dressed their children the same, or alike and kept them together in one bedroom as babies and sometimes as young children too, they also envisaged a time when this would end because their children would develop their own (different) tastes and personalities and be old enough to have a say in these decisions. 
Second, related to this, this construction of twinship (two same-looking, close children) means that twins potentially face a series of more intense contradictions as they grow up: whilst they are expected to be the same as children (especially young children) they are expected to become different and whilst they are expected to be together, they are expected to become independent (see Bacon, 2010). Whilst twin sameness and togetherness might be admired and cherished in early childhood, normative life course timetables suggest that these should ideally be kept in check by parents and teachers and increasingly diluted over time in order to ensure that twins progress towards adulthood successfully (see Bacon, 2010).

Adults who present as 'twins' may thus become the source of social stigma. As Rachel (aged 20) explained to me when talking about some twins that attended her university, 'it's a bit weird. When you're 20 you really should have your own identity rather than being a twin' (2010: 96). Similar sentiments are reflected in popular media accounts of some adult twins too. For instance, my recent examination of tabloid representations of the pop duo 'Jedward' (see Bacon 2016a) revealed how they were often represented as Other, 'freaks', 'children' and 'jokers'/'a joke'.

Failure to complete this developmental process towards individuality and independence successfully will, so the story goes, result in a series of 'problems'. Research reveals that concerns over the 'problems' of separation are common amongst teachers and parents. Summarising research conducted on teacher's attitudes in the UK, US and Australia, Tully, Moffitt, Caspi, Taylor, Kiernan \& Andreou (2004) note that teachers often believed that separation was necessary if the twin relationship was stifling the development of twins' individuality and independence. The main reason that teachers listed for keeping twins together was that twins could also provide each other with a valuable source of support. In relation to parental attitudes, Segal and Russell's (1992) research in America found that slightly more parents said that their twins should be placed together during the early grades than apart. Parents of identical twins were also slightly more likely to favour this than parents of non-identical twins. The main reasons given for keeping twins apart related to opportunities to develop individuality, independence and individual abilities as well as the opportunity to eliminate competition or comparison by others. The main reason for keeping them together was that twins could provide each other with a sense of security amidst 
change. Similarly Preedy's research in the UK found that the main reason given by schools for keeping twins together was because twins were seen as a source of support to each other, or because of parental request. The main reasons given for placing them in different classes were 'parental request, to develop independence, dominance of one twin by the other and restriction of one twin by the other' (Preedy, 1999, p.74).

In line with this, parenting guides encourage parents to think about whether to keep their children together as they move through school - separation at secondary school is usually advised in order to avoid problems linked to over-reliance, excessive competitiveness and the academic under-development of one twin. Recent guidance from TAMBA (Twins and Multiple Births Association) suggests that:

In the beginning, as long as the children enjoy each other's company and are not overly competitive, they are likely to benefit from starting together. Having siblings in the same class usually makes it easier to settle in - especially if they don't know the other children. They can be separated later - and often are by the age of eight (TAMBA, 2015).

We can pick up some of these concerns in Anthony and Clare's accounts too.

This section has examined some of the discourses of childhood, twinship and growing up that shape and frame parenting practice and one aspect of the social context within which twins experience being twins. The next part of this chapter explores another dimension of this family context by examining inter-generational relationships between parents and children and the intra-generational relationships between siblings.

\section{(ii) Generation and power}

Scholars within Childhood Studies - noteably Berry Mayall and Leena Alanen - have pointed to the importance of recognising generation as both a structuring principle of social organisation and a lived social process. Generational inequalities are embedded within the 
economic, political and cultural realms of society and therefore children - as a social group may be said to have different experiences and life chances to 'adults' (Alanen 2001).

Adults have divided up the social order into two major groups - adults and children with specific conditions surrounding the lives of each group: provisions, constraints and requirements, laws, rights, responsibilities and privileges. (Mayall 2000, p.120)

However, generation does not just exist and operate at the level of 'structure'. Rather, as Alanen (2001) reminds us, it is something that is done, lived and reproduced and thus something that necessitates agency. The notion of generationing, as an adjective, allows us to capture generation as a social process; it defines generation as a practice rather than as a 'thing'. Hence, through 'childing' practices' and 'adulting practices', people become constructed as 'children' and 'adults' (Punch 2005). Generation also operates horizontally as well as vertically. Different generations of children, experience different kinds of childhoods. Today we fear that young people will be worse off than their parents, less likely to own property and more likely to carry huge debts into adulthood. Both dimensions shape the kinds of experiences that twins have.

\section{Inter-generational relationships}

In line with their emphasis on childhood innocence, Anthony and Clare's 'childing' and 'adulting' practices upheld a strong-adult child boundary founded on difference: parents were parents and children were children. This principle of social organisation was almost taken-forgranted. Rules relating to age appropriateness commanded authority because adult parents had made them: 'that's top and bottom of it' (Clare); 'it's as simple as that' (Anthony). This intergenerational division was further legitimised by notions of age-related competency and development. For Anthony, then, being eight meant not being able to take on board information about sex and swearing but being a parent meant he could assess and decide when the 'right time' would be. Whilst for now, Anthony and Clare made many key decisions that shaped their children's everyday social lives, including what clothes their twins should wear, more room for choice would emerge with time as their children's competencies to make decisions and their personalities developed. 
Just how far this reflects broader social patterns relating to adult-child relationships in families is difficult to establish. 'Modern childhood is often portrayed in terms of enhanced democratic relationships between parents and children with the assumption that children's negotiating power has increased over time' (Jensen and McKee 2003, p. 1). The actual extent of this development is debateable and certainly variable. Research suggests that social class, gender and age may all be significant factors shaping power relations between parents and children. For instance, Lareau's (2002) research suggests a more equal relationship may be more prevalent amongst middle class families. My research (2010) (although small in scale) suggests that democratisation may be more established in families when children are older because they are deemed more competent to make decisions (and sometimes mistakes). In her research on UK childhoods, Mayall (2002) found that children and young people tended to see their mothers as the person who managed the household and interacted with children and that girls were generally more restricted in their use of public space (see Bacon, 2016b for a fuller overview).

Certainly children remain 'highly dependent on their parents' material resources' (Mayall 2002 , p. 47) and this shapes the context within which childhood and twinship happens. Nonintact families are more likely to be unemployed and children in lone parent families remain one significant social group 'at risk' from being in poverty. Indeed, their risk of falling into poverty has increased since 2010/11 to 2015/16 (see Joseph Rowntree Foundation 2017). Whilst twins and triplets are more likely than singletons to be born to parents who are married and living together (so we might expect this to have a protective effect against low incomes and deprivation) more parents of multiples say they are financially worse off compared to parents of singletons and they are more likely to use up some or all of their savings compared to families with singletons. Mothers with multiples consider returning to work later than mothers with singletons and are also less likely to work than other mothers. Child care is a significant issue. Whilst the proportions of parents paying for childcare is about the same for parents of multiples and parents of singletons, parents of twins pay double. There are no additional state benefits for families with twins and multiples and multiple birth children are more likely than other children to be living in families on a lower income (McKay 2010). 
Parents make decisions about the family home - they choose, buy or rent houses and, in my study (Bacon 2010) they tended to decide how to initially allocate bedroom space too-opting to keep their child twins together as babies and (sometimes) small children. According to Punch (2005), this kind of 'resource power' (control over children's access to income, material goods, time and space) enhances parents' 'legitimate authority'. The latter is conferred to parents by children because they expect their parents to know more and to protect them. Hence, their parents' authority is justified by their generational location and social position in the family. For twins, parents' resource power potentially feeds into whether or not they have to share a room or not, shapes how much time they spend together at home and their social experiences of being twins inside and outside the home. In my study (Bacon 2010) 15-yearold twins Hannah and Charlotte shared a bedroom in their three bedroomed-house. Mum Caroline had her own room and she did not want to put Charlotte and Hannah's younger sister Ellie in a room with one of the twins 'because of the age gap'; she reasoned that 'boyfriends' could not be in the same room as 'dolls' (see Bacon, 2010: 74). Sharing a room was a source of much frustration for Hannah and Charlotte and they found other ways to get their 'own' space by naming and claiming objects and sections of space in their bedroom. Hannah especially, searched out space where she could be alone in private - choosing the bathroom because 'there's a lock on [the door] and no one can get in' (Bacon, 2010: 141). They also often spent time apart from each other at school and after-school with their own friends.

Intra-generational relationships

As Charlotte and Hannah's experiences start to illustrate, another important relationship that shapes twins' lives is their relationship with each other. Research examining sibling relationships have a different character to parent-child relationships. Punch's research (2001, 2005, 2008a, 2008b and McIntosh and Punch 2009) demonstrates that sibling relationships tend to involve more disputes, bargaining and the use of physical power. Notwithstanding these general differences, sibling relationships vary and change. Amongst other things, gender and 'perceived' age-hierarchies between children, structure sibling relationships (see Bacon, 2012 for an overview). 
Within parenting guides and psychological research, twins' relationships are often depicted as being more intense than sibling relationships. My research (Bacon 2010) found that, in some respects, twins' relationships with each other shared many characteristics with sibling relationships: they encompassed a mixture of feelings and functions ranging from intimacy, comfort and support to irritation and conflict (Dunn 2008; Punch 2008b). In other respects twins' relationships may be different to siblings'. Twins may have to share the attention of their parents (Pulkkinen, Vaalamo, Hietala, Kaprio \& Rose, 2003), be encouraged to act the same (Koch 1966) or be referred to as a pair (Kozlak 1978). All these things make the social situation of being a twin 'unique' and may influence their relationship with each other. For example, Koch suggested that identical twins may develop close relationships with each other because they are expected to be close and may be given more areas of common experience. Similarly, Kozlak (1978, p. 115) noted that since twins are 'dressed alike and possess physical similarities, [they] learn to behave as twins and identify with each other'.

Unlike singleton sibs, twins occupy the same generational location - usually born minutes apart. If notions of age and stage separate singleton children from one another, then they also situate twins at 'the same' age and stage. Thus, in my study (Bacon 2010) Mike (a father to twins) said twins were different to singleton children because singleton children were 'at different stages' (Bacon, 2010: 56). In this sense, their shared generational location affirms their sameness. Caroline's insistence that 'dolls' could not be in the same space as 'boyfriends' reveals how parental interpretations of the significance of age and generation can help to shape the kinds of spaces provided for twins at home and the kinds of relationships that they develop with each other within and through them.

For twins, sharing is a significant (and for older child twins especially, often a frustrating) aspect of their social experience. Sharing a bedroom often meant that they could not always use space and objects in the ways they wanted to. Amongst other things, the (female) twins recalled disputes over which music to play, sharing make up and borrowing/taking clothes. Sharing a room also restricted their ability to achieve privacy, manage the information /images they revealed about themselves and to make self-determined choices about their own embodied experiences - such as going to sleep. Liam explained that sharing a room with his brother sometimes meant he could not watch what he wanted on TV or read a book with the 
light on without his brother complaining that he needed the light off in order to go to sleep (see Bacon, 2010).

Sometimes key changes - such as moving into separate bedrooms - were instigated by one of the two twins. These 'instigator twins' who pushed for change, were named with consistency and were always the older of the two twins. But being the oldest does not necessarily give twins (or siblings) automatic access to power. Reflecting findings from research about siblings (see Edwards, Hadfield \& Mauthner 2005; Punch 2008a), my twins study showed that in their everyday dealings with each other power moved between twins in different situations rather than always remaining consistently with one person.

\section{EXPLORING DIMENSIONS OF AGENCY}

The final part of this chapter now turns to focus more centrally on children's agency. Although the meaning of agency is disputed, here I utilise Mayall's (2002, p. 21) definition:

A social actor does something, perhaps something arising from a subjective wish. The term agent suggests a further dimension: negotiation with others, with the effect that the interaction makes a difference - to a relationship or to a decision, to the working of a set of social assumptions or constraints.

Agency involves action and initiating change (with intended and unintended consequences). It cannot be separated from structure, rather it is through agency that individuals respond to, reproduce, modify and potentially transform structures around them (Frankel 2017). To begin this section, the chapter returns to finish off the case study of 'Anthony \& Clare' by turning to examine their children's narratives: 'Ash and Harry'.

\section{Ash \& Harry}

Although Ash explained that he was "stuck' in the house all day, both Ash and Harry valued the experience of togetherness that being a twin brought. For Ash, it was the activities they did together at home (forming clubs, playing on the play station) that made being a twin 
'special'. Similarly, for Harry being a twin made him feel 'happy' because he had someone to play with. These young twins also played up their sameness. During my first interview with them, they encouraged me to participate in a game of 'spot the difference' - lining themselves up alongside each other, side by side, with Ash remarking 'You can hardly tell our clothes, that they're different' (Bacon, 2010: 96). They were wearing identical outfits and Ash, like his mum Clare, told me that it was his mum that made these decisions.

Whilst Ash and Harry both recognised that they had some physical and ascetic differences (different hair, Harry wears glasses) in their pictures they chose to emphasise sameness. Ash drew a picture of himself with his brother but rubbed out his initial version of his brother's nose in order to make it appear the same as his own. Harry also drew pictures of them both dressed in identical Nike T-shirts.

\section{(i) Interdependence and connection}

In her book Personal Life, Carol Smart $(2007$, p. 28) reminds us of the importance of acknowledging the embeddedness of agency: 'To live a personal life is to have agency and to make choices, but the personhood implicit in the concept requires the presence of others to respond to and contextualize those actions and choices.' This case study shows how Ash and Harry's experiences of being twins is shaped by them and for them. Whilst they enjoyed being together at home, using this time and space to develop games and clubs with each other, this togetherness was also something created and controlled by their parents. Whilst they used their agency to display and present particular identities to me, parents also provided the resources for this identity work. In these instances of interaction at home, Ash and Harry actively drew my attention to notice sameness that otherwise would not have been obvious. For instance, drawing pictures allowed them opportunities to present a version of self that may not have been immediately (if at all) observable. Indeed, they did not actually look physically similar to one another. Lining themselves up against each other allowed them to emphasise the only sameness that could be physically observed - their clothes. To make any aspect of this 'line up' feasible, they needed to work together and use each other as human resources. 


\section{(ii) Meaning-making}

Seeking to outline a more 'active' perspective on twinship, Stewart draws on Goffman to highlight how twins can be conceptualised as meaning-makers:

In the drama of twinship, the relevant actors are twins who, according to the model, may perform in face-to-face interaction, create impressions, manipulate perceptions and seek to control their audience. (Stewart 2003, p. 156).

According to Goffman (1969), actors make use of various props and settings to present their identities to others. One key resource that twins use in this respect is their clothes. Many of the older child twins that I spoke to wanted to distance themselves from notions of twinsameness. Peter told me, 'it's good to be different' and his twin brother lan said that whilst it was 'like a law that you have to wear the same clothes' as twins, 'I don't like to' (Bacon, 2010: 97). Although, as lan told me, 'we do have the same clothes' they chose not to wear them at the same time because 'people treat you more like one person'. Dan explained that he and his twin brother Liam wouldn't go out wearing the same thing 'unless it was a joke or something' and Charlotte said that whilst she did not mind being dressed in the same outfits as her sister when she was 'little', she would not like this now she is 'older' (see Bacon, 2010: 97).

This contrasts quite sharply with Ash and Harry's account and reveals how older twins were more likely to present themselves as and draw attention to the value of difference. These twins rejected the significance of dominant discourses of twin sameness for shaping their own lives. Instead, they drew on dominant discourses of growing up (which affirm that they are growing up 'successfully') to inform their actions and to try to modify and shape how others saw them. (For a fuller consideration of how twins use their bodies, space and talk to negotiate their identities, see Bacon 2010).

(iii) Generagency 
This chapter has shown that a significant dimension to children's agency is how it emerges from and operates within generational relationships. For instance, Ash and Harry's agency and their capacity to reproduce dominant discourses of twin sameness and togetherness required intra-generational interdependence and was facilitated by inter-generational decisions about dress and children's access to space inside and outside the home. Leonard (2016) captures these dynamics in her notions of generagency and inter- and intrageneragency. Generagency is agency within generational contexts - 'the term encapsulates the structural positioning of childhood while simultaneously acknowledging children's active agency in generational relationships' (Leonard 2016, p. 132). Inter-generagency relates to how children (and adults) intervene in and shape everyday social life as they take up and perform their roles as 'children' and 'adults' and as the inter-generational ordering of social life affords them varying degrees of power and control. Intra-generagency examines how children (who occupy the same structural position) negotiate the generational order. It helps us appreciate that though they may share a common structural location, they do not experience being children in the same ways and some will have more agency than others.

Agency, then, is not something that we simply possess. It is something that is achieved through our connections with others. Some contexts and relationships may provide more opportunities for stronger expressions of agency than others. As Klocker notes:

'thin' agency refers to decisions and everyday actions that are carried out within highly restrictive contexts, characterised by few viable alternatives. 'Thick' agency is having the latitude to act within a broad range of options. It is possible for a person's agency to be 'thickened' or 'thinned' over time and space, and across their various relationships. $(2007$, p. 85$)$

For instance, children's agency may be potentially thickened if parents afford children meaningful decision-making power and if siblings cooperate with and agree to the organisation, use and reclassification of 'shared' space. Agency may be thinned if parents establish rigid and hierarchical generational relations and siblings dominate and overpower their other sibs. Class, gender, ethnicity, age and disability are social divisions that will help to structure the degree of agency that groups of children and adults have. 


\section{Conclusions}

This chapter has shown how twins lives, identities and relationships are shaped by social and cultural contexts. Twins live out their lives against a cultural backdrop that stereotypes them as being 'the same', together and close and this makes being a twin different to being a sibling. These dominant discourses of twinship run parallel to dominant discourses of childhood and, as such, twinship is constructed as another, but more intense, way of being a 'child': dependent and lacking individuality. Parents of twins and twins themselves variously utilise these discourses, as well as understandings of growing up, to inform their actions. Sometimes their actions reproduce these dominant discourses and sometimes they challenge them. Inter-generational relations between parents and children and intra-generational relations shape and inform twins experiences and identity work and provide varying degrees of opportunity and constraint. Adults as well as other children can thicken and thin children's agency. In drawing attention to this, this chapter confirms the importance of seeing agency as relational, interdependent and emergent.

\section{References}

Ainslie, R. C., Olmstead, K. M. \& O'Loughlin, D. D. (1987). The early developmental context of twinship: some limitations of the equal environment hypothesis. American Journal of Orthopsychiatry 57(1), 120-124.

Alanen, L. (2001). Explorations in generational analysis. In, L. Alanen and B. Mayall (Eds.), Conceptualizing Child-Adult Relations (pp.11-22). London: Routledge.

Bacon, K. (2006). 'It's good to be different': parent and child negotiations of 'twin' identity'. Twin Research and Human Genetics, 9(1), 141-147.

Bacon, K (2010). Twins in society: parents, bodies, space and talk. Basingstoke: Palgrave Macmillan.

Bacon, K. (2012). 'Beings in their own right'? Exploring children and young people's sibling and twin relationships in the Minority World. Children's Geographies, 10(3), 307-319 
Bacon, K. (2016a). Tabloid constructions of twinship. Centre for the Study of Childhood and Youth. University of Sheffield, 5-7 th July 2016.

Bacon, K. (2016b). Children's use and control of bedroom space. In, S. Punch and R. Vanderbeck (Eds.) Families, intergenerationality, and peer group relations. In T. Skelton (editor-in-chief) Geographies of Children and Young People 5. (pp.1-21) Singapore: Springer. Burlingham, D. (1952). Twins: a study of three pairs of identical twins. London: Imago Publishing Company Ltd.

Corney, G. (1977). Mythology and customs associated with twins. In I. MacGillivray, P. P. S. Nylander and G. Corney (Eds.), Human Multiple Reproduction. (pp.1-15). London: W.B. Saunders Company Ltd.

Dunn, J. (2008). 'Sibling relationships across the life-span', in M. Klett-Davies (Ed.) Putting Sibling Relationships on the Map: A Multi-Disciplinary Perspective. London: Family and Parenting Institute.

Edwards, R., Hadfield, L. \& Mauthner, M. (2005). Children's understandings of their sibling relationships. London: National Children's Bureau.

Foucault, M. (1980). Power/Knowledge. Hemel Hampstead: Harvester / Wheatsheaf.

Frankel, S. (2017). Negotiating childhoods. London: Palgrave Macmillan.

Giddens, A. (1991). Modernity and self-identity. Stanford: Stanford University Press.

Gillis, J.R. (2003). Childhood and family time: a changing hisorical relationship. A.-M. Jensen, and L. McKee (Eds.), Children and the changing family: between transformation and negotation. (pp. 149-164). London: Routledge.

Goffman, E. (1969). The presentation of self in everyday life. London: Penguin.

Hendrick, H. (2015). Constructions and reconstructions of British childhood: an interpretive survey, 1800 to the present. In A. James and A. Prout (Eds.), Constructing and reconstructing childhood (Classic Edition) (pp.29-53), London: Routledge.

Hockey, J. and James, A. (1993). Growing up and growing old. London: Sage.

Hockey, J. and James, A. (2003). Social identities across the life course. Basingstoke: Palgrave Macmillan.

James, A., Jenks, C. \& Prout, A. (1998). Theorizing childhood. Cambridge: Polity Press. Jenks, C. (1996) Childhood. London: Routledge. 
Jensen, A.-M. and McKee, L. (2003). Introduction: Theorising childhood and family change. In A.-M. Jensen and L. McKee (Eds.) Children and the changing family: between transformation and negotiation (pp.1-13 ). London: Routledge.

Joseph Rowntree Foundation (JRF) (2017). 'Child poverty by family type' available at:

https://www.jrf.org.uk/data/child-poverty-family-type [last accessed 28/07/17].

Klocker, N. (2007). An example of 'thin' agency: Child domestic workers in Tanzania. In R. Panelli, S. Punch, \& E. Robson (Eds.), Global perspectives on rural childhood and youth (pp. 83-94). London: Routledge.

Koch, H. L. (1966). Twins and twin relations. London: University of Chicago Press.

Kozlak, J. B. (1978) Identical twins: perceptions of the effects of twinship. Humboldt Journal of Social Relations, 5(2), 105-130.

Lareau, A. (2002). Invisible inequality: social class and childrearing in black families and white families. American Sociological Review, 67(5), 747-776.

Leonard, M. (2016). The sociology of children, childhood and generation. London: Sage.

Leonard, M. R. (1961). Problems in identification and ego development in twins.

Psychoanalytic Study of the Child, 16: 300-320.

Mayall, B. (2000). Conversations with children: working with generational issues. In P.

Christensen and A. James (Eds.), Research with children: perspectives and practices (109124). London: Falmer.

Mayall, B. (2002). Towards a sociology of childhood: thinking from children's lives. Buckingham: Open University Press.

Mittler, P. (1971). The study of twins. London: Penguin Books.

McIntosh, I. and Punch, S. (2009). "Barter", "Deals", "Bribes" and "Threats": Exploring sibling interaction. Childhood, 16(1), 49-65.

McKay, S. (2010). The effects of twins and multiple births on families and their living standards. Birmingham: University of Birmingham in association with TAMBA.

McNamee, S. (2016). The social study of childhood. London: Palgrave Macmillan.

Mittler, P. (1971). The study of twins. London: Penguin Books.

Newman, H. H. (1942). Twins and supertwins: a study of twins, triplets, quadruplets and quintuplets. London: Hutchinson's Scientific and Technical Publications.

Piaget, J.(1929). The child's conception of the world. Savage, MD.: Littlefield Adams.

Piaget, J. (1930). The construction of reality in the child. New York: Basic Books. 
Preedy, P. (1999). Meeting the educational needs of pre-school and primary aged twins and higher multiples. In A. Sandbank (Ed.), Twin and triplet psychology (pp. 70-99). London: Routledge

Pulkkinen, L., Vaalamo, I., Hietala, R., Kaprio, J. \& Rose, R. J. (2003). Peer reports of adaptive behaviour in twins and singletons: is twinship a risk or an advantage? Twin Research, 6(2): 106-118.

Punch, S. (2001). Household division of labour: generation, gender, age birth order and sibling composition. Work, Employment \& Society, 15 (4), 803-823.

Punch, S. (2005). The generationing of power: a comparison of child-parent and sibling relations. Sociological Studies of Children and Youth, 10, 169-188.

Punch, S. (2008a). Negotiating the birth order: children's experiences. In M. Klett-Davies (Ed.), Putting sibling relationships on the map: A multi-disciplinary perspective (pp. 30-49). London: Family and Parenting Institute.

Punch, S. (2008b). "You can do nasty things to your brothers and sisters without a reason": siblings' backstage behaviour. Children in Society, 22(5), 333-344.

Rousseau, J.-J. (1979) [1762]. Emile or an education. New York: Basic Books.

Segal, N. L. and Russell, J. M. (1992). Twins in the classroom: school policy issues and recommendations. Journal of Educational and Psychological Consultation. 3(1), 69-84.

Sharon, T. and Wooley, J. D. (2004). Do monsters dream? Young children's understanding of the fantasy/reality distinction, British Journal of Developmental Psychology, 22(2), 293-310. Smart, C. (2007). Personal life. Cambridge: Polity Press.

Stewart, E. (2003). Exploring twins: towards a social analysis of twinship. Basingstoke: Palgrave Macmillan.

TAMBA (2015). Twins or more at school: together or apart? Available at: https://www.tamba.org.uk/Parenting/Primary/Separation [last accessed 25/07/16].

Tully, L.A., Moffitt, T.E., Caspi, A., Taylor, A., Kiernan, H. \& Andreou, P. (2004). What effect does classroom separation have on twins' behaviour, progress at school, and reading abilities? Twin Research, 7(2), 115-124.

Woodhead, M. (2013). Childhood a developmental approach' in, M. J. Kehily (Ed.),Understanding childhoods: a cross disciplinary approach (pp. 99-149). Bristol: Policy Press in association with The Open University. 
Zazzo, R. (1978). Genesis and peculiarities of the personality of twins. In W. E. Nance (Ed.), Twin research: Part A: psychology and methodology, Vol. 24 (pp.1-11). New York: Alan R. Liss.

Zelizer, V. (1985). Pricing the priceless child: the changing social value of children. New York: Basic Books. 